\title{
Principles for the Danish biomonitoring programme*
}

\author{
Peder Agger
}

The National Forest and Nature Agency; Slotsmarken 13, DK-2970 Hørsholm

\begin{abstract}
A national programme for monitoring wildlife and its habitats has been set up in Denmark, the background being decades of severe environmental problems and degradation. The aim is to obtain a minimal coverage of the dominant types of landscapes, supplemented by special attention to endangered species and habitats. Collaboration with other institutions and amateur organizations has been given high priority.
\end{abstract}

\section{INTRODUCTION}

Natural phenomena and human activities are almost continously changing the living conditions for wild flora and fauna. It has become increasingly obvious that human impact is of the greatest significance for the often dramatic changes we have seen in the environment during the last decades.

In many countries of the world, therefore, biomonitoring is at the top of the agenda for the institutions dealing with nature conservation and environmental protection. It might be useful as a way of obtaining the information needed both for the conservation of wildlife itself and (by using the wildlife as indicators) for the monitoring of the human environment.

The two words "monitoring" and "surveillance" are often used as if they were synonyms, which might cause some confusion. The latter means an activity where the shape, extent or abundance of something is obtained, whereas monitoring, besides the pure registration, also can include an act of giving warning or advice to those who have the possibility of acting on the advice - the management.

Some authors make a distinction between what they call "control monitoring" and "trend monitoring". This may be for practical reasons as in Denmark, where to some extent the institutions which "control" are not the same as those which follow the trends. In any case, monitoring in the sense given above is limited to change over a period of time i. e. it is trend monitoring which constitutes the main part of the programme described below.

In Denmark, the management of the environment is divided between institutions working with nature conservation, and institutions working with environmental pollution. Within the Ministry of Environment we thus find an agency for (forest and-) nature, and an agency for environmental protection. The same pattern is found at the regional

\footnotetext{
* Presented at the VI International Wadden Sea Symposium (Biologische Anstalt Helgoland, Wattenmeerstation Sylt, D-2282 List, FRG, 1-4 November 1988)
} 
level in the sections for nature and landscape protection, and sections for environmental protection i.e. water protection. The main emphasis of the programme described in the following paper is on wildlife, i.e. nature conservation. Monitoring programmes on chemical substances such as pollutants will not be presented here.

\section{OBJECTIVES}

In 1986, an advisory board with representatives from the administration, different research institutions and non-governmental-nature-organizations (NGOs), was established to offer proposals on how a national monitoring programme could be set up. In its report the objectives were defined as:

Establishing a long-term programme for standardised repeated registration of certain species of wild flora and fauna and their habitats to allow possible trends and their causal relations to be detected.

The purpose of the programme was described as being:

(A) To increase the present field of knowledge and establish a more precise background for planning.

(B) To create an "alarm system" for detecting any unforeseen unacceptable impact on the environment before it is too late ("trend monitoring").

(C) To estimate the effect of counteractions that may be taken, ("control monitoring" ?).

In addition to the statistics obtained on flora, fauna and habitats (the surveillance), it was recommended that the reseachers involved in the programme should also be aware of the possible causes of change and make suggestions and predictions for possible counteractions.

\section{STRUCTURING THE PROGRAMME}

The first programme emphasized the importance of getting at least a minimal coverage of all regions and types of landscapes fagricultural areas, forests, urban areas, wetlands, heathlands, grasslands and the sea). Within each of these, some habitats, species or groups of species were chosen as indicators. They are being registered either in total or (more often) in samples. This part of the programme can be considered as the "coarse grid" mentioned by Noss (1987).

As the coarse grid is not able to record all that is needed (i. e. endangered species or types of habitats), it is supplemented by a "fine grid" of special monitoring programmes, for example on harbor seal, orchids, raised bogs and chalk fens.

Keywords for this programming have been geographical coverage of the more abundant species and more thorough investigation of the endangered, most sensitive and/or valuable parts of nature.

It has, however, also become necessary to make some other more practical decisions: existing programmes have been re-examined to find out whether they can be considered fit for further use. Coordination has become necessary in order to make methods and records compatible. Methods have been developed where methodology had not yet been developed, or have been adjusted to Danish conditions. A picture of how these considerations have been followed is given in Table 1 . 
Table 1. 31 monitoring projects recommended for 1988

\begin{tabular}{|c|c|c|c|}
\hline $\begin{array}{l}\text { Type of } \\
\text { landscape }\end{array}$ & $\begin{array}{l}\text { Permanent monitoring } \\
\text { programmes }\end{array}$ & $\begin{array}{l}\text { Research projects and } \\
\text { inventories }\end{array}$ & $\begin{array}{l}\text { Methodological } \\
\text { projects }\end{array}$ \\
\hline \multirow[t]{3}{*}{ Salt marsh } & $\begin{array}{l}\text { Monitoring birds in } \\
\text { Ramsar- and EEC-bird } \\
\text { protection areas }\end{array}$ & $\begin{array}{l}\text { Repetition of older } \\
\text { registrations of vege- } \\
\text { tation }\end{array}$ & \\
\hline & $\begin{array}{l}\text { Monitoring program- } \\
\text { mes in the scientific re- } \\
\text { serves }\end{array}$ & $\begin{array}{l}\text { Projects in the scienti- } \\
\text { fic reserves }\end{array}$ & $\begin{array}{l}\text { Special projects at the } \\
\text { field stations }\end{array}$ \\
\hline & Resting sites for geese & $\begin{array}{l}\text { Designation of further } \\
\text { localities for monitor- } \\
\text { ing }\end{array}$ & \\
\hline \multirow[t]{2}{*}{ Heathland } & Lichen-heaths & $\begin{array}{l}\text { Designation of further } \\
\text { localities for monitor- } \\
\text { ing }\end{array}$ & \\
\hline & & $\begin{array}{l}\text { Causes for decrease in } \\
\text { bird populations }\end{array}$ & \\
\hline \multirow[t]{2}{*}{ Fens and bogs } & $\begin{array}{l}\text { Vegetation in raised } \\
\text { bogs }\end{array}$ & $\begin{array}{l}\text { Repetition of older in- } \\
\text { vestigations of vegeta- } \\
\text { tion }\end{array}$ & \\
\hline & $\begin{array}{l}\text { Vegetation in other } \\
\text { bogs }\end{array}$ & & \\
\hline \multirow[t]{3}{*}{ Lakes and ponds } & $\begin{array}{l}\text { Orchids at selected } \\
\text { sites }\end{array}$ & & \\
\hline & $\begin{array}{l}\text { Lobelia- and Desmi- } \\
\text { diacé-lakes }\end{array}$ & $\begin{array}{l}\text { Review of nitrogen } \\
\text { and phosphate effects } \\
\text { on wildlife }\end{array}$ & $\begin{array}{l}\text { Public participation in } \\
\text { monitoring }\end{array}$ \\
\hline & $\begin{array}{l}\text { Amphibians and rep- } \\
\text { tiles }\end{array}$ & & \\
\hline \multirow[t]{2}{*}{ Brooks and rivers } & $\begin{array}{l}\text { Expanded biological } \\
\text { surveillance in reci- } \\
\text { pient control }\end{array}$ & & \\
\hline & Otter & & \\
\hline \multirow[t]{3}{*}{ The sea } & $\begin{array}{l}\text { Monitoring birds, bot- } \\
\text { tom flora and fauna }\end{array}$ & $\begin{array}{l}\text { Review of nitrogen } \\
\text { and phosphate effects } \\
\text { on wildlife }\end{array}$ & \\
\hline & Seals & & \\
\hline & Common porpoise & & \\
\hline \multirow[t]{2}{*}{ Forests } & Bird counts & $\begin{array}{l}\text { Monitoring wildlife in } \\
\text { relation to forest de- } \\
\text { cline }\end{array}$ & $\begin{array}{l}\text { Monitoring common } \\
\text { animal species in the } \\
\text { state owned forest di- } \\
\text { stricts }\end{array}$ \\
\hline & Lichen on trees & & \\
\hline Permanent grassland & & & $\begin{array}{l}\text { Methods for monito- } \\
\text { ring insects }\end{array}$ \\
\hline Agricultural areas & Bird counts & & $\begin{array}{l}\text { Monitoring small eco- } \\
\text { topes and insects }\end{array}$ \\
\hline Urban areas & & & $\begin{array}{l}\text { Registration of species } \\
\text { and habitats in urban } \\
\text { areas }\end{array}$ \\
\hline
\end{tabular}




\section{ORGANIZING THE PROGRAMME}

The monitoring section has 12 employees (incl. 8 biologists) in the office, and a field staff of 10 (at the 5 field stations). Furthermore, the section can count on a budget enabling 10-20 people to be employed on a yearly basis as short-term consultants.

Attempts to coordinate and initiate monitoring of wildlife as an inclusive part of other ongoing environmental monitoring programmes is given high priority. Institutions monitoring forestry, fishery and agriculture have been approached.

High priority is also given to collaboration with the universities. It is from here that we may expect the most constructive criticism currently needed on the methodological and theoretical aspects of monitoring.

The county councils also play an important part in nature monitoring. They have monitored a number of protected areas, mainly fens and saltmarshes, with regard to flora and bird life and to following the effect of management. Likewise, there is a coordination with the national agency concerning the monitoring of orchids.

Last but not least, the NGOs should be mentioned. Some of the best monitoring has been carried out by members of these organizations. Their specialized knowledge and their ability to mobilize large numbers of observers all over the country make them especially worthy of integration as partners in the overall programme (Fig. 1).

In its first year, all these considerations have had influence on the programme described in Table 1. One part of the programme consists of projects already started years ago i. e. at the five field stations (Fig. 2).

Another part of the programme consists of projects where parts of registrations made earlier within a university research programme are now repeated. Other projects aim at the application of methods usable in the surveillance of, for example, amphibians, insects and certain types of habitats. A third part of the programme is not visible in Table 1. It is the monitoring that is already included in other programmes. These programmes are run by other institutes primarily aiming at other aspects of the environment (i. e. in relation to forestry and environmental pollution) (Fig. 3). It is to be hoped that many more such programmes will be organized in the future.

\section{DATA AND INFORMATION}

The communication of what has been observed is considered an integral part of the national monitoring programme. It is planned that all the single observations should be converted into a form where they can be stored in the central EDP - d a ta base. A service will be instituted whereby institutions and individual persons will be supplied with extracts from the files on request.

Besides the datacentre, a bank of environmental samples (animal and plants, whole or in parts, soil and water samples) has been planned. The aim is to store samples that can be used as references for future analysis of i.e. trace elements of which we are not aware today.

Each of the individual monitoring projects $\mathrm{rep}$ or $\mathrm{t}$ annually and their reports are published in a technical form, and a moderate number printed. Every year, a more popular report summarizing the overall results and recommendations from the reports will be issued. This is presented at an annual meeting open to all consultants, administrators and the public. 

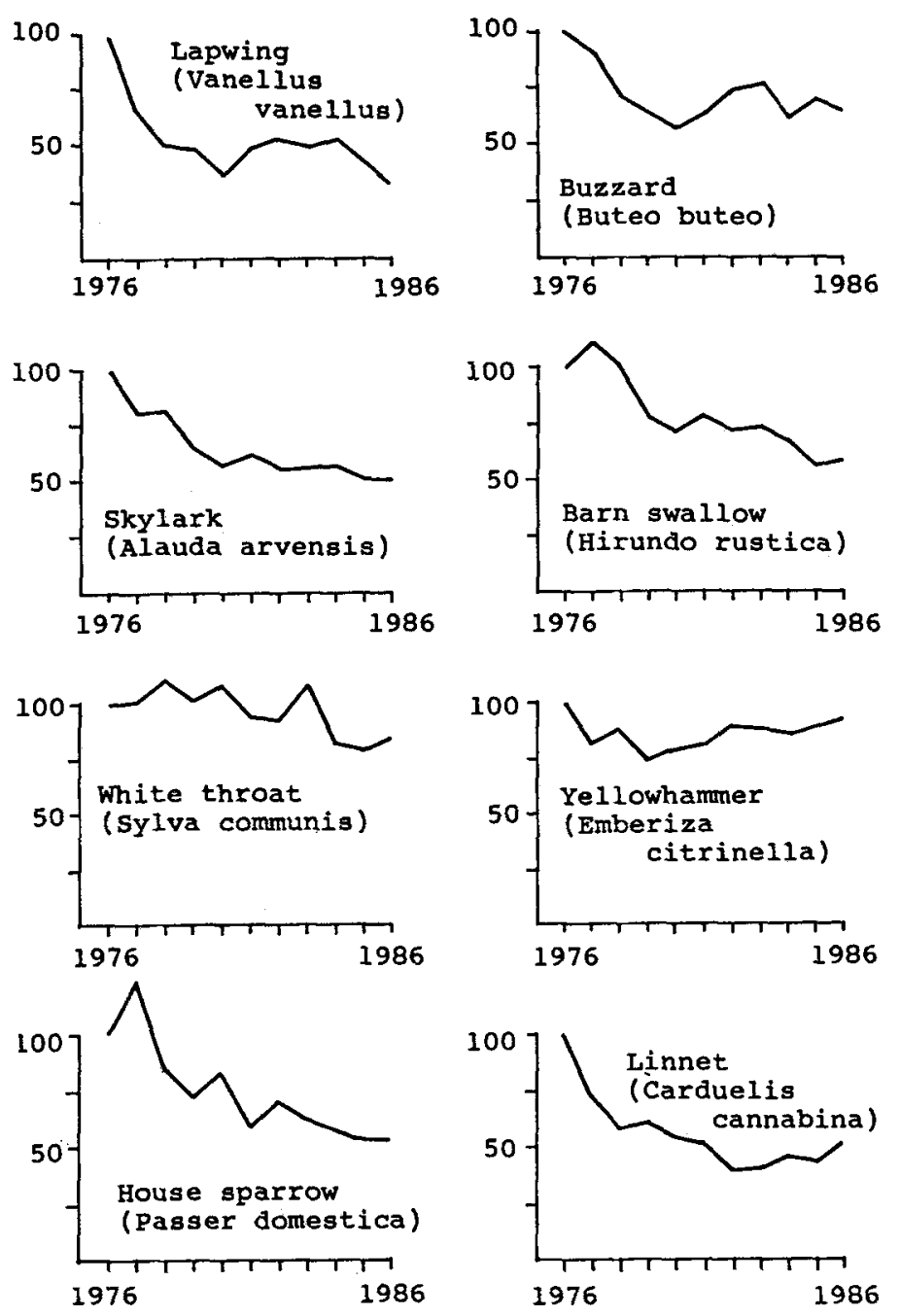

Fig. 1. An example of monitoring data obtained in collaboration with amateurs. Bird counts are made yearly at 20 points along 80 routes in representative rural areas. The counts in $1976=100 \%$

Along with the summarizing reports, a statistical yearbook on environmental data and data on wildlife has been planned. This as well as the databank will be executed in close collaboration with the national agency for environmental protection.

\section{PROBLEMS}

The rather idealistic description however hides many problems. Firstly there are all the problems related to the detection of the small effects in a complex of hardly detectable traces. Two principal answers can be given to this. One is to find sensitive 


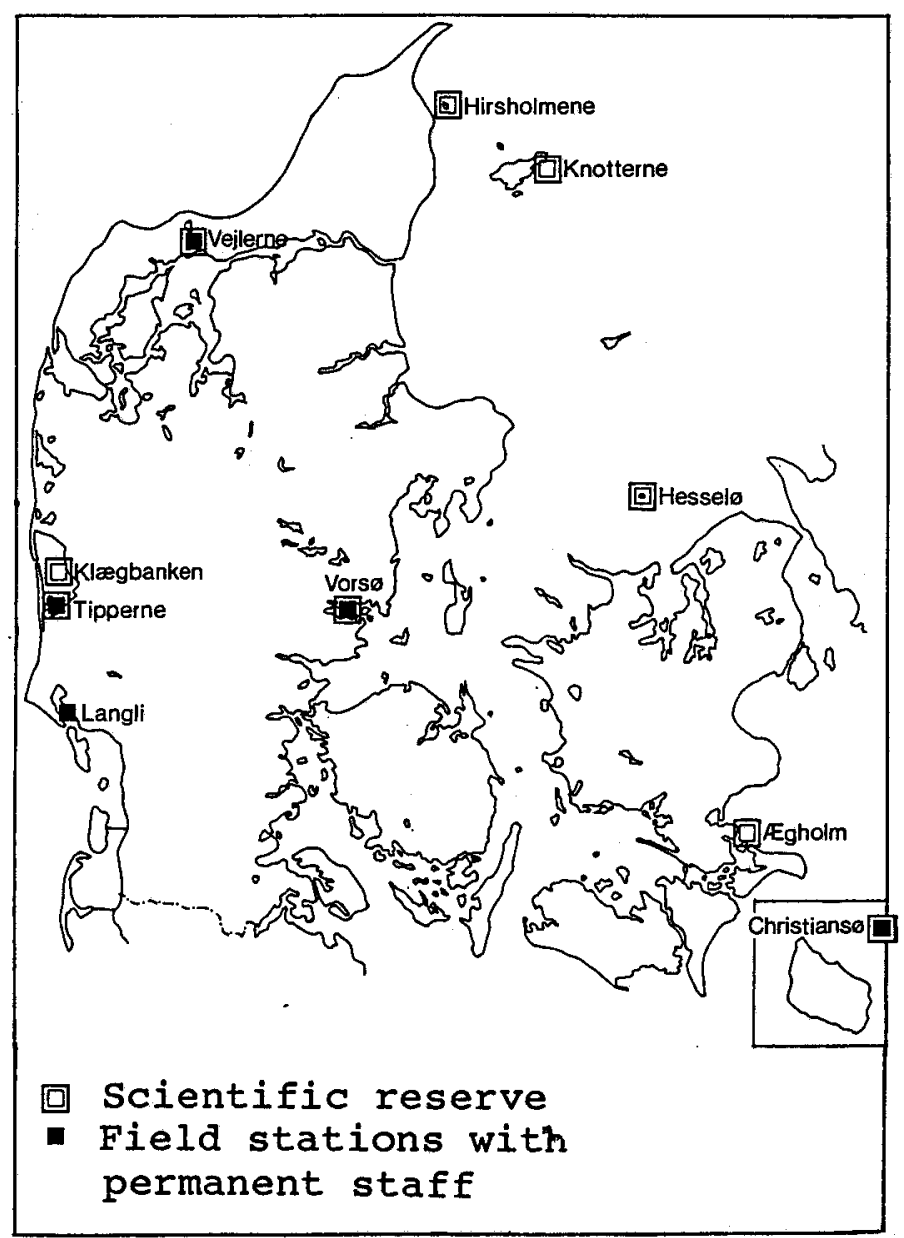

Fig. 2. Field stations and scientific reserves

indicators, the other is to establish series that will be recorded over a long period of time. Both of these, however, give rise to other problems.

Indicators are very attractive both from a methodological and an economical point of view. The problem is to find out what are good indicators. According to NERC (1976), the term indicator species, has been used to describe stenotopic species, whose distribution is limited by a narrow tolerance to some environmental factor. (The term is also used to describe species which are dominant under certain conditions.)

In general, we may say that an indicator is any measurable feature that can give information on the status or the changes in a wider part of the environment than itself. The criteria for a good indicator are that it should indicate subtle effects - not obvious ones, and it must be clear what it is indicating besides itself. Therefore, a good indicator should at the same time be potentially abundant and sensitive to human impact. Finally, a good indicator should be easy to find and identify. 


\section{number of hare}

- - number of grey partridge

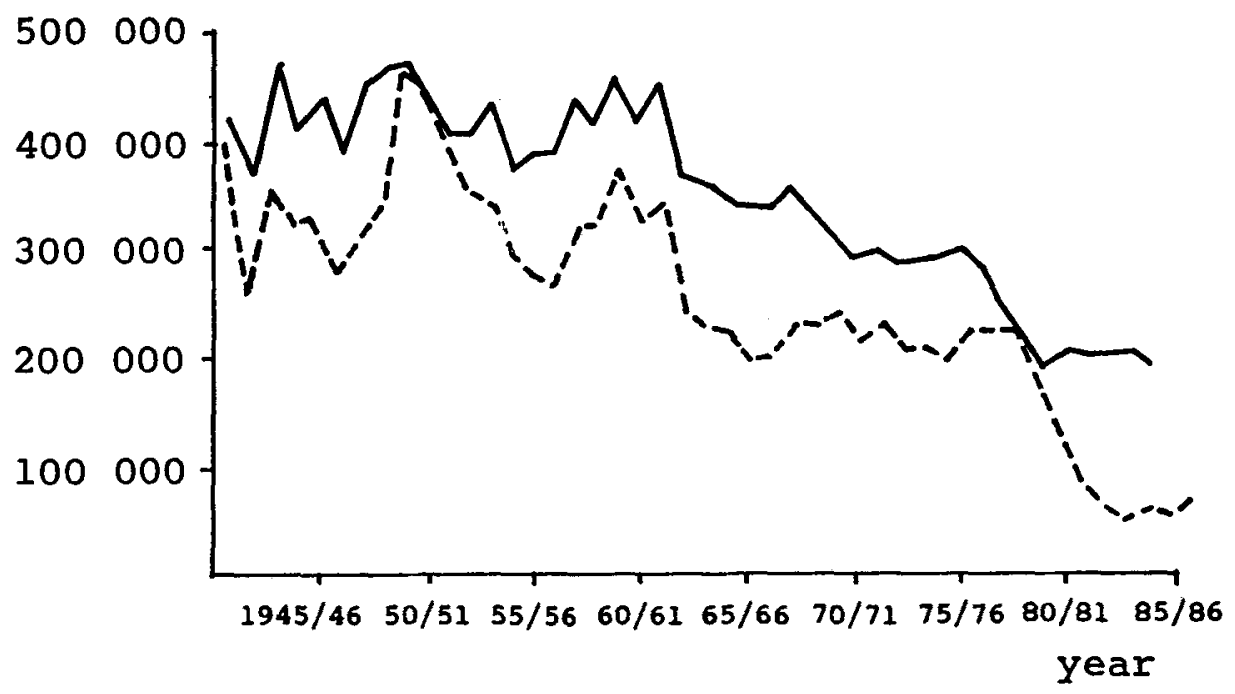

Fig. 3. An example of already existing registrations that can be integrated in the national monitoring programme: all hunters renewing their license are asked what they bagged in the previous year. The curves show the total number bagged yearly of hare (Lepus europaeus) and grey partridge (Perdix perdix). In the same period the total number of hunters increased from 87000 in 1941 to 170000 in the 1980 s

Given these criteria, it is obvious why birds and flowering plants are some of the indicators most commonly used. Because of beauty, size and recognizability they receive attention both from the public and from amateurs. However, we often lack knowledge when it comes to explaining what they are indicating. As examples of indicators, birds of prey can be mentioned (for 'pesticides), lichens (for acidification) and wildlife of oligotrophic communities (for eutrophication).

Endangered species are often the relatively most sensitive. Therefore monitoring "red list"-species is an acceptable part of the above mentioned "fine grid". It is, however, important for the general monitoring programme also to include other species than those qualified to be in the "red data book". For example, species which - even though common - have been exposed to a remarkable decrease in abundance (i.e. being reduced by more than $50 \%$ in the last decade) are obvious candidates for special attention (see Fig. 3).

Taub (1987) concludes on the use of indicators in monitoring that "two different types of work are needed: (1) a critical examination of the myriad of proposed indices using existing data and (2) new, tightly focused research on identifying promising indicators of change that might be more useful in describing and potentially predicting human impacts."

Collection of series over a long period of time should be planned in a way that makes 
distinction between local changes and more widely distributed general trends possible. This makes climax vegetation more obvious for monitoring than vegetation in younger successional stages. For the same reasons, localities influenced by local emission of pollutants should preferably be avoided. In Sweden, the whole national monitoring programme is consequently built up on a network of 20-30 stations for integrated monitoring located in areas with climax vegetation (Bernes, 1985).

In intensively cultivated landscapes and in marine environments, only the omission of localities with local disturbances can be made whereas the confinement to climax vegetation as the only type of locality for surveillance is impossible or at least inadequate.

S e c ondly, it is an obvious problem to limit the number of data and samples to the minimum needed. Besides the practical problem of handling data there is also the theoretical problem of analysing data that have been sampled without sufficient ecological considerations. As pointed out by Gray (1976), monitoring programmes often ignore that ecology has a theoretical base, and inadequate design or execution are a waste of both manpower and money.

On the other hand, we cannot sit and wait for the ideal to come along. As Frankel \& Soule said (1981): "Conservationists cannot afford the luxury of methodological elegance. We are soldiers in a war and soldiers must be pragmatists. Thus, it is our tenet that crude initiatives based on rough guidelines are better than the paralysis of procrastination induced in some scientists by the fear of inadequate data." Our answer to this dilemma is openness to criticism of the whole monitoring programme from those outside.

Thirdly, the bookkeeping - the mere surveillance of numbers and distribution of wildlife is in itself of limited interest. The crucial questions whenever any trends have been observed are, why? And what can be done about it? Therefore, already in the planning stage it has to be decided which of the most obvious courses of change should be included in the field work. Besides this, a national network of stations for integrated monitoring of both physical and chemical data and wildlife is planned parallel to the Swedish "PMK-stations" (" $\mathrm{P}$ " for programme, "M" for environment, $\mathrm{Sw}$. milieu, and " $\mathrm{K}$ " for quality, Sw. kvalitet).

Our contribution to this network will be some of the field stations. The plan is to expand the network up to 13 stations on land and 10-15 at sea. At these stations a minimal programme should go on permanently. Besides that, any institution planning any environmental monitoring will be encouraged to use these stations whenever appropriate. This should improve the chances for unveiling the courses of changes.

\section{SUMMARY}

A national programme for monitoring wild plants and animals and their habitats is under construction in Denmark. It is a diverse programme covering many types of nature and run by many different institutions including both government agencies, county councils, universities and amateur organizations. The programme is to a large extent based on indicator species and it is restricted to the monitoring of wildlife. Together with the national agency for environmental protection, a network of fixed stations for integrated monitoring both of biotic and abiotic parameters is planned. 


\section{LITERATURE CITED}

Bernes, C. (Ed.), 1985. Monitor 1985 - PMK: På vakt i naturen. Naturvårdsverket, Stockholm, $207 \mathrm{pp}$.

Frankel, O. H. \& Soulé, M. E., 1981. Conservation and evolution. Cambridge Univ. Press, Cambridge, $78-79$.

Gray, J., 1976. Are base-line surveys worthwhile? - New Scient. 29, 219-22.

National Environment Research Council, 1976. Biological surveillance. Report of the NERC working parties on biological surveillance in the marine, freshwater and terrestrial environments. - NERC Publ. (Ser. B.) 18, 1-24.

Noss, R. F., 1987. From plant communities to landscape in conservation inventories: a look at the nature conservancy (USA). - Biol. Conserv. 41, 11-37.

Taub, F. B., 1987. Indicators of change in natural and human impacted ecosystems: Status. In: Preserving ecological systems; the agenda for long-term research and development. Ed. by S. Draggan, J. J. Cohrssen \& R. E. Morrison. Praeger, New York, 129 pp. 